\title{
Governance in Maritime Passenger Transport: Green Public Procurement of Ferry Services ${ }^{+}$
}

\author{
Kristin Ystmark Bjerkan *(1), Hampus Karlsson *, Rebecka Snefuglli Sondell, Sigrid Damman (i) \\ and Solveig Meland \\ SINTEF, Postboks 4760 Torgarden, 7465 Trondheim, Norway; rebecka.s.sondell@ntnu.no (R.S.S.); \\ Sigrid.Damman@sintef.no (S.D.); Solveig.Meland@sintef.no (S.M.) \\ * Correspondence: kristin.ystmark.bjerkan@sintef.no (K.Y.B.); hampus.karlsson@sintef.no (H.K.) \\ † This paper is an extended version of a paper presented at 32nd International Electric Vehicle Symposium 2019 \\ (EVS 32), Lyon, France, 19-22 May 2019.
}

Received: 3 October 2019; Accepted: 4 November 2019; Published: 6 November 2019

check for updates

\begin{abstract}
Governance is central for sustainability transitions in maritime transport. Norwegian authorities can directly influence developments in maritime transport through green public procurement, and low- or zero-emission technologies have been or are being considered for more than 250 operational ferry and high-speed vessel connections. This study explores practices of green public procurement and investigates procuring authorities and operators' perspectives on the efficiency of green public procurement in accelerating sustainability transitions. Through review of calls for tender and interviews with procuring authorities and operators, the study identifies critical issues for green public procurement to accelerate maritime passenger transport toward sustainability. The critical issues are related to either procedural or service delivery issues. Procedural issues refer to timelines with multiple calls on the same time and different views of procurers and operators on the ideal duration of contracts. The most demanding service delivery issues are infrastructure for charging and energy capacity in remote areas where operators have to pre-book energy needs based on rough estimations which in turn increase the tender price.
\end{abstract}

Keywords: governance; sustainability; maritime transport; public procurement

\section{Introduction}

Norwegian authorities have high ambitions of moving maritime transport toward sustainability. They have launched a variety of tools and strategies to facilitate transitions among ship owners, ports, and authorities on local and national levels. This array of incentives and policies is an example of how governance can be actively applied to steer and manage sustainability transitions [1,2].

Governance can be defined as "the totality of interactions in which public as well as private actors participate, aimed at solving societal problems or creating societal opportunities; attending to the institutions as contexts for these governing interactions; and establishing a normative foundation for all those activities" [3]. The role of governance in accelerating transition in maritime transport, however, has historically been limited by the marginal influence of national authorities, the relative power of the shipping industry, and the international character of this industry. The potential of governance is therefore greater in progressing sustainability transitions in purely domestic segments. Hence, green public procurement of ferry services has emerged as a promising approach for directing maritime passenger transport toward sustainability in Norway.

This study is conducted within the frame of the Mobility Zero Emission Energy Systems (MoZEES; www.mozees.no) research center and explores and describes the practices of governance in transitioning domestic maritime passenger transport toward sustainability. It particularly focuses on the practices of 
green public procurement and how procuring authorities and operators experience the efficiency of green public procurement in accelerating sustainability transitions. The paper thus revolves around two research questions:

1. What characterizes green public procurement of maritime passenger transport in Norway?

2. What issues are critical for green public procurement to accelerate sustainable transitions in maritime passenger transport?

Green public procurement is a particularly prominent issue in the Scandinavian countries with a mixed economy, and where a large part of public budgets is dedicated to the purchase of public services. The national budget agreement of 2015 announced that all new tender competitions for public maritime transport should include requirements for zero- or low-emission technologies whenever it was available. Given the large number of domestic ferry and high-speed vessel connection in Norway, green public procurement in particular could be expected to accelerate the transition toward more sustainable maritime passenger transport.

The research questions are investigated through a review of eleven tenders for maritime passenger transport services, as well as interviews with procurers and contractors associated with these tenders.

The next section of this paper introduces understandings of governance and its role in progressing sustainable technologies through, for instance, green public procurement. Thereafter, methods and data used to explore the research questions are presented, followed by a review of nine critical issues for accelerating sustainable transitions through green public procurement. Finally, the paper summarizes main findings and discusses the results' implications for the practice field.

\section{Theoretical Background and Methods}

\subsection{Governance and Sustainability}

The concept of governance has evolved over the last century, from being a theory of how to rule (planning) to becoming a theory of how to implement [4]. As such, governance pursues the same goals and achievements as a government, but is distinguished by the processes that underlie the achievement of these goals [5]. Unlike the government, governance includes the actions of the state as well as non-public actors such as communities, businesses, and Non-governmental organizations (NGOs) [6]. Neo-institutionalist approaches to governance especially emphasize the importance of private markets in governance, and the freedom of actors to enter into contracts to fulfill necessary functions and access resources [7]. Economic approaches to governance, exemplified through new public management, have introduced market-oriented policies aimed at facilitating, for instance, exit options, competition, accountability, and monitoring [8].

There is a growing body of literature on the governance of sustainable technologies. In proposing a framework for analyzing the governance of sustainable technology innovation, Hillman et al. [9] refer to four mechanisms in governance which can be directed at the demand side or supply side-regulatory mechanisms (absolute policies through control and hierarchy), market mechanisms (market design, taxes, subsidies, and investment support), cognitive mechanisms (consensual knowledge and problem framing), and normative mechanisms (values and beliefs of what is 'good'). Inspired by cultural theory, Tukker and Butter [10] claim governance of sustainable transitions is largely fatalist, hierarchist, individualist, or egalitarian, whereas Kemp et al. [11] refer to policy integration, shared perspectives, information, incentives, and system innovation programs as key components in governing sustainability. Transforming technologies in a sustainable direction depends on governance which succeeds in pressuring existing technologies as well as providing and coordinating resources which allow markets and technologies to change and adapt [12].

An expanding field of theory and research addresses sustainability governance under the branch of transition management. Transition management devises a prescriptive framework for shaping transitions through strategic, tactical, operational, and reflexive activities [13]. These activities allow 
for developing systemic instruments and process strategies for enabling transitions [14]. As such, transition management is a governance approach [2] and a practice-oriented model for influencing ongoing transitions in more sustainable directions [15]. As with other governance approaches, transition management focuses on processes as much as objectives [16]. The orientation toward market instruments (e.g., ecotaxes, subsidies, tradeable permits, and certification) derives from difficulties with implementing more conventional, regulatory instruments [6]. For instance, it has proved difficult to regulate sea transport due to its international character, which requires regulation on supranational levels.

\subsection{Governing Sustainability in Transport}

Although van Leeuwen [17] argues that regionalization of maritime governance has produced stricter environmental standards and increased enforcement, the transnational nature and long history of self-regulation in maritime transport have caused it to lag behind environmental governance in other sectors [18]. Roe [19] refers to several reasons for governance failure in the maritime sector: national maritime policies have little impact, institutions which develop and implement maritime policies are not able to define necessary policies, lack of involvement from stakeholder groups outside maritime value chains (media, politicians, interest groups, etc.), overwhelming power of shipowners, and lack of dynamic policy design.

Hoogma et al. [20] give a thorough description of eight groups of barriers which obstruct sustainable technologies from gaining ground in the transport sector, whereof many relate to the role and potential influence of governance and policy making. For instance, they refer to the lack of direction of policy makers and inadequate regulation as barriers toward developing, investing in, and planning for use of particular technologies. Insecurity in turn allows manufacturers to justify the status quo as there is no secure market with a predictable consumer demand. They argue that the lack of legislation and financial support for marketing of new technologies reduces willingness to invest in new technologies. Governance can further reduce barriers in providing or adapting infrastructure which reduces hesitations to invest.

This is reflected in other studies. Nilsson and Nykvist [21] call for several governance strategies to accelerate sustainability transitions in road transport, which could be equally relevant to maritime transport. They suggest that such governance relies on strong and clear political objectives and strategies with explicit technology prioritization and substantial integration of policies relating to climate, environment, and transport. They further promote public-private partnerships and fleet procurement to increase familiarity with new technologies.

On an international level, there are several examples of market-based incentives for ships to improve environmental footprints, such as green port dues and indexes for clean shipping, energy, and environmental performance [22-24]. Given the (semi-)public ownership of many ports [25], these represent one aspect of sustainability governance in maritime transport. Another prominent aspect is green public procurement.

\subsection{Green Public Procurement}

The Organization for Economic Co-operation and Development [26] defines public procurement as the "purchase by governments and state-owned enterprises of goods, services and works" carried out "efficiently and with high standards of conduct ... ". Within the European Union (EU), green public procurement (GPP) is voluntary, but there is a wide range of EU policies supporting green public procurement [27] and that form the foundation of its handbook on green public procurement [28]. Public procurement has the potential to stimulate innovation [29] and to promote emerging technological niches [30]. A substantial literature examines the impact of public procurement on innovation (e.g., [31-34]). As realizing potential benefits of innovation relies on the expertise and efficiency of actors in the relevant value chain [35], green public procurement is closely related to private-public partnerships [36-38]. 
Public procurement can rest on a number of procedures, which are discussed in several studies (e.g., [39-41]): Open tendering allows any actor to make a bid on a public tender with set and determined requirements, whereas restricted tendering involves a stage of pre-qualification. Tenders with negotiations allow prequalified bidders to negotiate with the procurer on any aspect of the tender, including technology, price, and contractual features [42]. Similarly, competitive dialogue gives the procurer an opportunity to maintain a dialogue with a number of pre-qualified contractors to discuss how the procurer's needs can be fulfilled in a possible offer [43] and involves dialogue with pre-qualified bidders, which enable the procuring authorities to modify and tune criteria and requirements. Finally, in a development procedure, a research project makes up the basis for the procurement process with the aim to build knowledge and find new solutions [44].

Although not explicitly focusing on maritime transport, existing research does to some degree refer to specific criteria and assessments included in green public procurement. In a recent review of scientific literature on green public procurement, Cheng et al. [45] identify prominent environmental assessment criteria, including technical requirement and eco-labeling. Although price and quality typically receive higher weight than environmental criteria, green criteria and standards could also be used for screening bidders and reducing the number of available bidders. Alhola [46] gives an overview of 31 environmental award criteria used in calls for tenders in Finland, Sweden, and Demark, where the most prominent criteria are environmental policy, environmental management systems, and other less specific, environmental criteria. A Finnish study [47] further investigates environmental criteria in transport-related procurement contracts, and finds criteria in procurement related to eco-driving, age and emission standards of vehicle fleets, oil leaks, and hull bottom paint.

Given the mixed economy of Scandinavian countries and the heavy reliance on the public sector's ability to engage private actors to deliver their services, public procurement represents a major activity and responsibility on all administrative levels in Norway [48]. As local and regional authorities enjoy substantial autonomy, they are fairly free to control and shape their own procurement ambitions and procedures. In an empirical study of environmental criteria in the public procurement of Norwegian counties and municipalities, Michelsen and de Boer [49] found that three of four criteria include environmental performance criteria in public procurement, and that these requirements are typically related to environmental management systems. Another study [50] found that approximately $70 \%$ of public tenders included some sort of environmental requirements, and that emissions, fuels, and energy are prominent requirements in tenders for local and regional transport services [51].

The ability of green public procurement to produce environmentally benign outcomes relies, however, on a range of factors other than the mere inclusion of environmental criteria in awarding contracts. This includes the cost-benefit of the greener option and budgeting, the presence of or lack of supporting policies and legislation on all political levels and in the procuring organization itself, support from management and defined strategies, knowledge about market opportunities, and the dynamics between internal pressure and market resistance as well as the quality and availability of green solutions $[29,30,52]$.

The success of sustainable public procurement is further determined by the degree to which the behavior of procurers themselves is sustainable [53]. The procurer, however, can hold many different traits. Gelderman et al. [54] emphasize three actor groups as particularly central in shaping public procurement: the institutional top management, procurement professionals, and budget owners. Testa et al. $[27,55]$ therefore call for a determined public administration with sufficient awareness and competence of procurement on all levels and greater awareness and (legal, economic, and technical) training throughout procuring organizations. They further emphasize the value of dedicated personnel with defined roles, functions, and responsibilities in procurement, and claim that the resources of individual procurers are more important than procedures. 


\subsection{Norwegian Policies for Sustainable Maritime Transport}

Norway has an ambition of being a frontrunner in sustainable transport, and the national transport plan for 2018-2029 [56] states that 40\% of all local shipping shall run on low- or zero-emission solutions by 2030. Most recently, the national government banned all carbon emissions in the United Nations Educational, Scientific and Cultural Organization (UNESCO) world heritage fjords. Green shipping is therefore a priority area for the Norwegian government, and the government's maritime strategy [57] launches comprehensive policy instruments.

The use of more environmentally friendly fuels is a core element, and the maritime strategy [57] considers gas (LNG), biofuels, and electricity (including onshore power and hybridization) to have the greatest potential. Onshore power and renewal of the short distance fleet are particularly prominent and are further supported by the national port strategy which includes tax discounts for environmentally friendly vessels. The maritime strategy [57] aims to further develop instruments supporting R\&D, piloting, and commercialization of solutions for more environmentally friendly shipping. It emphasizes the importance of using cost-effective instruments to support investments in environmentally and climate-friendly maritime transport, developing an overall plan for increased use of onshore power, and making requirements for low- and zero-emission technology in ferry tenders when technology warrants it. It also holds ambitions to further develop international regulations on climate and environmentally friendly shipping, both through the International Maritime Organization (IMO) and the EU.

The objectives of the maritime strategy [57] are supported by a range of instruments and support schemes, some of which are presented in Table 1. The support schemes administered by Enova are particularly prominent. Enova is fully owned by the Ministry of Climate and Environment and supports public and private projects for improving energy efficiency and reducing climatic emission through innovation and technology development.

Among other instruments that indirectly may accelerate sustainable technologies in maritime passenger transport are the national emission taxes. As per 2018, the Norwegian general tax rate for $\mathrm{CO}_{2}$ emissions is approximately EUR 50 per ton $\mathrm{CO}_{2}$ equivalent. The parallel sulfur tax has also been substantially increased in the recent years [58]. Other relevant schemes include support for renewal in local shipping and risk loans for financing new construction in local shipping. Furthermore, the Norwegian Export Credit Guarantee Agency (GIEK) mitigates risk for banks and other finance institutions through a domestic ship guarantee scheme.

Table 1. Selection of instruments for sustainable maritime transport in Norway.

\begin{tabular}{|c|c|}
\hline Scheme & Description \\
\hline Enova & $\begin{array}{l}\text { A state enterprise owned by the Ministry of Climate and Environment. } \\
\text { Administers a range of relevant support schemes. }\end{array}$ \\
\hline Pilot-E & $\begin{array}{l}\text { Grant scheme provided by Enova, the Norwegian Research Council and } \\
\text { Innovation Norway. Supports development and implementation of } \\
\text { environment-friendly technology, with grants equivalent to more than EUR } \\
10 \text { million in } 2018 \text {. Maritime transport has so far been a key target area. }\end{array}$ \\
\hline Klimasats & $\begin{array}{l}\text { Support scheme for local and regional authorities which grant support } \\
\text { initiatives which reduce climate emissions or facilitate transitions to } \\
\text { sustainable societies. }\end{array}$ \\
\hline Chart for green coastal traffic & $\begin{array}{l}\text { Forum for co-creation of knowledge and innovative solutions in the } \\
\text { maritime industry. }\end{array}$ \\
\hline Environmental technology scheme & $\begin{array}{l}\text { Targets companies in all sectors with the aim to stimulate innovation and } \\
\text { reduce the financial risks associated with promising solutions at an earlier } \\
\text { stage of development (TRL 5-7). }\end{array}$ \\
\hline $\begin{array}{l}\text { Support for climate and } \\
\text { environmentally friendly shipping }\end{array}$ & $\begin{array}{l}\text { Encourages collaboration between private actors in the development of } \\
\text { zero- and low-emission ships. }\end{array}$ \\
\hline $\mathrm{NO}_{\mathrm{x}}$ fund & $\begin{array}{l}\text { Enterprises may join by making payments per } \mathrm{kg} \mathrm{NO}_{x} \text { emitted, at a lower } \\
\text { rate than the national } \mathrm{NO}_{x} \text { tax. Support is paid back to the industry } \\
\text { through the } \mathrm{NO}_{x} \text { Fund's support scheme. }\end{array}$ \\
\hline Emission taxes & Taxes on $\mathrm{NO}_{\mathrm{x}}, \mathrm{CO}_{2}$, and sulfur. \\
\hline
\end{tabular}


Norwegian authorities consider public procurement a useful tool to become a "zero-emission nation" [59]. Since January 2017, state, county, and municipal administrations are obliged to develop their procurement practice in order to contribute to reduce environmental impacts and promote climate-friendly solutions whenever relevant. Correspondingly, a new paragraph added to the Regulation on Public Procurement, emphasizes that environmental requirements and criteria may be applied in all steps of the procurement process, and that, where applied, they should be weighted to minimum $30 \%$. Through requirements and incentives in the procurement of ferry services, national authorities expect to stimulate technology implementation to reduce $\mathrm{CO}_{2}$ emission from the ferry sector (Norwegian Government, 2016). Furthermore, a parliament resolution (no. 873, 2016) specifically encourages the use of development contracts for hydrogen ferries. The Norwegian Public Roads Administration and more recently, Trøndelag county, have deployed strategic procurement of innovation in this area.

A parliamentary bill from 2017 suggested that low- or zero-emission solutions for maritime passenger transport services should be a requirement in public procurement processes whenever possible. Although green public procurement might be picking up for local ferries and passenger vessels, an overview of public tender competitions in Norway indicated that there is a considerable potential for improvement by including environmental criteria [51]. In 2017, 15 million Norwegian kroner were allocated to the Agency for Public Management and eGovernment (Difi) to develop an improved scheme for green public procurement. Further, the Confederation of Norwegian Enterprise (NHO) recently published guidelines for public procurement of passenger transport. Although not obligatory for tenders for regional roads, there is an available template that procurers can confer with.

\subsection{Methods}

The purpose of this paper was to explore the practices of governance in transitioning maritime transport toward sustainability, with a particular focus on green public procurement of maritime passenger transport services. The research questions were studied through application of two different qualitative methods: document studies and interviews. Qualitative methods are particularly useful for accentuating processes and meaning [60] and allow the researcher to understand how individuals understand and interpret their surroundings [61].

The characteristics of green public procurement was explored through document studies of calls for tender for maritime passenger transport services. More specifically, eleven calls for operation of 19 ferry services throughout Norway were investigated. All calls were published between 2015 and 2018 and were identified through the Norwegian national database for public procurement (www.doffin.no). This selection did not include all calls from this period; hence the selection might not be fully representative. But the investigated tenders had in common that they all included the most important procurers and service operators. When available, tender documents were downloaded from the database, but were also requested directly from the procurer's contact person. The procuring authority of ferry services for national roads is the Norwegian Public Roads Administration (NPRA) Directorate of Public Roads, while ferry services for sub-national roads are procured by county authorities represented by a designated public transport administration company or regional representatives of the NPRA. The calls for tender included here were examined with respect to requirements for quays and infrastructure, vessel requirements, other environmental criteria, and award criteria.

Interviews were conducted with procuring bodies and operators in order to better understand what issues are critical for accelerating sustainability transitions in the ferry segment of maritime transport. Interviews were approved by the Norwegian Center for Research Data and were performed in accordance with their guidelines. All interviewees were sent information about the study ahead of the interviews and were asked for consent to participate. In total, three procurers and two operators were interviewed during the second half of 2018. Both the operators represented actors with a large market coverage, whereas the three procurers represented a region within the NPRA (two interviewees) and a public transport administration company (one interviewee). The main difference between 
procurers was that ferry services connecting national roads and procured by the NPRA are required to facilitate zero-emission solutions, whereas county roads administered by county authorities or public transport administration companies are merely encouraged to do the same. In many cases, however, the NPRA assists county authorities in procuring ferry services for county roads, and the NPRA interviewees included in this study therefore had experiences from procurement processes which do and do not follow national zero-emission requirements.

The interviewees were recruited through purposive sampling [62,63]: Interviewees representing procurers were recruited based on the review of tenders described above, and winning tenders were in turn used to identify and recruit interviewees representing operators. The interviews were conducted in person and as telephone meetings. They were based on a semi-structured interview guide, which is useful when the researcher holds some knowledge of the main topic (here, sustainability in maritime passenger transport), but has less knowledge of what relevant sub-topics might be (here, for instance, contract duration and fuel supply infrastructure) [64]. The interview guide included five topics: (1) background information about the informant and his/her organization, (2) knowledge and implementation of low- and zero-emission technologies in own organizations, (3) joint ventures and cooperation regarding emerging technologies, (4) procurement and tender processes, and (5) incentives and support mechanisms for sustainable maritime transport.

Data from the interviews were analyzed with the software program Nvivo in order to sort and categorize the data and to allow mapping critical issues for accelerating sustainability transitions. In step 1, all the interviews were reviewed and their content was coded with reference to background of the topics in the interview guide. In step 2, a positive, neutral, or negative value was added to the interviewees' statements. In step 3, the coded text was analyzed, using the codes to compare the statements about one topic across all the interviewees, and to see how frequent the topic was mentioned. When juxtaposed with coded statement values, this might indicate if a particular topic or issue is considered a barrier or accelerator for sustainability transitions.

The interviewees provided valuable reflections on green public procurement in transitioning maritime passenger transport toward sustainability. However, in interpretation of the results, one should bear in mind that the operators represent businesses where a sound company economy is a prerogative and where sustainability transition in the maritime passenger sector is a secondary (or tertiary) objective. Further, these operators represented two of the largest ferry service providers in Norway, and their perspectives are not necessarily representative of the view of smaller operators or operators less successful in winning tenders.

\section{Results}

\subsection{Characteristics of Procurement of Ferry Services}

The following sections present the analysis of eleven calls for tender for ferry operations in Norway, with respect to requirements for quays and infrastructure, vessel requirements, other environmental criteria, and award criteria. All but two calls include requirements about reduction of the emission characteristics of the vessel. These can relate to the use of specific technologies, such as electric propulsion, or they can relate to specified limits on emissions (see Table 2). Some calls also require low-, zero-, or non-fossil technologies without referring to a specified technology or fuel. Some of the calls include exceptions from these requirements for reserve vessels or temporary vessels, but should these be used for longer periods they must comply with the general requirements. 
Table 2. Vessel requirements on propulsion and emission restrictions.

\begin{tabular}{cc}
\hline Type of Vessel Requirements & Number of Calls for Tenders \\
\hline Fully electric vessel & 4 \\
Partly electric vessel & 1 \\
LNG or non-fossil fuels & 2 \\
Limits on emissions and/or energy use & 4 \\
\hline
\end{tabular}

Some calls also require a minimum operation time without needing to recharge or refuel, which could potentially restrict the opportunities for electric solutions. One call, for instance, requires a fully electric vessel to continue operating at least $3 \mathrm{~h}$ if charging is unavailable and that other zero- or low-emission solutions must be able to maintain operation for minimum $12 \mathrm{~h}$ without refuel or recharge.

Quay infrastructure also determines the possibility for using electric solutions. Calls for tender usually specify the available quays and their characteristics, and nine of the reviewed calls specify that onshore power supply will be available to the operator. A majority of the calls also allow modifications of the quays to comply with the operator's needs. In most cases, the operator will be responsible for planning, making, and financing the modifications, and must also adhere to relevant plans and regulations. In one call, however, the procurer itself assumes the responsibility for providing onshore infrastructure.

Some calls for tender allow financial support for environmental upgrading to be subtracted from the bid price. For instance, a few calls request information about possible funding from Enova and several calls ask the tenderers to specify whether they are eligible for funding from the $\mathrm{NO}_{x}$ fund. By subtracting support for emission-reducing measures from the tender price, tenderers with lower emissions are indirectly rewarded.

Mandatory monitoring and reporting on environmental performance are included in a handful of the calls. These require tenderers to report on fuel consumption, for example, by implementing a Ship Energy Efficiency Management Plan, a monitoring tool developed by the International Maritime Organization. Other calls demand ISO 14001 certification or similar standards for environmental management and control. Several calls also open for sanctions if the operator does not comply with contracted emission limits.

There are two main methods for evaluating tenders in a public procurement process. The lowest price approach evaluates the bids that are subject to a set of minimum requirements based on price only. The most economically advantageous tender (MEAT) approach, on the other hand, allows for a variety of quality aspects to be considered when evaluating the bids, such as environmental impact [65]. While both the approaches are in use, the latter has gained popularity in recent years and is also recommended by the European Commission [66]. Among the call for tenders reviewed here, four calls apply the lowest price approach and do not apply any environmental criteria in the evaluation. However, the same four calls require either fully electric vessels or place restrictions on emissions and fuel consumption. The other seven calls in the review apply the MEAT approach, combining price and other, primarily environmental and award, criteria. The weight given to price varies between $70-85 \%$ and the environmental criteria are given a weight between $15-20 \%$. One of the calls includes quality as a criterion instead of environmental aspects. The content of the environmental criterion varies from case to case and includes indicators, such as energy use, $\mathrm{CO}_{2}$ emissions, $\mathrm{NO}_{\mathrm{x}}$ emissions, and environmental efficiency.

\subsection{Critical Issues for Success}

The interviews with the three procurers and two operators allow for identifying a set of critical issues that influence the ability to transition to zero-emission solutions. They can be categorized into procedural issues and service delivery issues. The former category relates to characteristics of 
the public procurement process, while the latter refers to issues that concern the ability to deliver a zero-emission service (see Table 3). The following section presents the critical issues that are identified.

Table 3. Critical issues for successful green public procurement in maritime passenger transport.

\begin{tabular}{cl}
\hline & \multicolumn{1}{c}{ Critical Issues } \\
\hline \multirow{3}{*}{ Procedural } & Timelines \\
& Contract duration \\
& Standardization \\
& Requirements \\
& Environmental weights \\
\hline & Technology lock-in \\
Service Delivery & Techology costs \\
& Infrastructure and \\
& charging/refueling \\
& Energy capacity and cost \\
\hline
\end{tabular}

\subsubsection{Procedural Issues}

The interviewees provided their perspectives on the procurement procedures, typically applied for maritime passenger transport: negotiated procedure, development procedure, and competitive dialogue procedure. Although the negotiated procedure approach demands a large administrative capacity and risks exposing conflictual issues, the operators appear positive to this approach and some would like it to be used more often. They describe it as useful for clarifying uncertainties and avoiding misunderstandings. Further, they suggest that the competitive dialogue approach allows operators to give inputs to and shape the content of the tender, and both procurers and operators recall positive experiences with the development procedure. Although it is considered an expensive approach, it provides both procuring authorities and operators with valuable knowledge and learning opportunities when testing new solutions.

Timelines: Tight timelines are a key challenge presented by the interviewees. Frequently, multiple calls for tenders coincide, and the operators therefore struggle to participate in all relevant tenders. The uneven temporal distribution of calls also has a negative impact on workflow, access to capital, and available expertise. This affects the operators as well as dockyards and design offices. In addition, delivering new technological solutions or installing vessels with existing zero- or low-emission technologies within a limited timeframe comes with a risk of elevating final costs, delivery problems, or delays. In consequence, it might in some cases only be feasible for an existing operator with available vessels to submit realistic offers. This may limit competition in the public procurement processes to a few large operators.

Contract duration: Procuring authorities and operators have different opinions regarding the ideal duration of contracts. Long contracts imply that the same technological solution is used for a long period of time, without the possibility to implement new technology and update existing vessels if improved solutions should emerge. Procurers experience this inflexibility, as they strive to continuously upgrade the energy performance of ferry connections. With the current system, a new procurement process is needed in order to update or change outdated technology, which is both costly and time-consuming for the procurer. However, operators prefer longer contracts to ensure predictability in their own operations and they capitalize on sunk investments as vessels remain in use.

Standardization: Several interviewees ask for more standardization in the public procurement process, particularly regarding requirements, sanctions and weights in the evaluation process. This could make the process more resource-efficient. The public procurement process is to some extent already standardized and must comply with the standard procedure for public procurement. In addition, the confederation of Norwegian Enterprise (NHO) in cooperation with regional administrations have published new guidelines for procurement of public transport which can contribute to simplify the process in the future. 
Requirements: Interviewees consider technical requirements a significant influence on the implemented solution. One operator claims cheaper diesel solutions will continue to be the standard unless calls include zero-emission technology as a specific requirement. In addition to specified propulsion technology, other technical specifications can indirectly influence the feasibility of zero-emission solutions. For example, speed requirements can obstruct zero-emission solutions because fully electric solutions are currently unsuited for high speeds. Operators further suggest that anchoring zero-emission ambitions in their organization produces low-emission solutions even though they are not required in calls: internal policy strengthens the operators' environmental focus and justifies time spent on developing low-emission solutions.

Weighting: The use of weights in the award process is criticized by several interviewees. Firstly, they argue that weighting environmental aspects instead of applying minimum environmental criteria weakens the environmental standard. The successful use of environmental weighting assumes generally high environmental ambitions among operators. Interviewees consider it more likely, however, that environmental weighting lowers the bar for operators' environmental ambitions. Instead of meeting high predefined environmental standards, they now only have to offer a better bid than their competitors-whose environmental ambitions are not necessarily high. Thus, the tender with the highest environmental weights might not have a large environmental impact. Instead, by using minimum environmental criteria, the procurer can determine and raise the operators' ambitions.

Secondly, interviewees argue that large environmental weights could allow the operators to set unreasonably high prices, resulting in unrealistic tenders. Some of the interviewees further emphasize that price declines in low- or zero-emission solutions level the playing field for environmental-friendly technology and traditional solutions, rendering environmental criteria less necessary.

\subsubsection{Service Delivery Issues}

Technology lock-in: Closely related to the issue of contract duration is the fear of lock-in among both procuring authorities and operators. As seen above, procurers call for more flexibility to upgrade during the contract period to keep up with the technological development and environmental standards, whereas operators are afraid to lose their competitive edge due to an outdated fleet. Currently, contracts are already shorter than the lifetime of vessels, and considering the fast technology development, the operators risk ending up with a fleet that is no longer competitive in subsequent procurement processes. The risk of losing competitivity can be mitigated through contract options which allow flexibility in transition phases between contract periods. This could allow the operators to use their existing fleets for 1-2 years after the original contract has expired, thus giving time to replace their fleets or adapt them to stricter environmental requirements.

Technology costs: The opinions on technology costs are somewhat divided among the interviewees. Some note that diesel solutions are still cheaper than zero-emission solutions and hence argue that calls for tender should require zero-emission technology. Others underline that the price of zero-emission technology has declined significantly in recent years, to the extent that zero-emission solutions in several cases are competitive with traditional diesel propulsion technologies. This development is only representative for vessels with electric propulsion systems. For other solutions, such as hydrogen, the costs still are higher than for diesel because of high production cost as well as need for new infrastructure for refueling.

Energy capacity and cost: Although zero-emission propulsion technology is ready to be put into use, the infrastructure to support electricity-powered maritime transport remains underdeveloped. Interviewees address problems related to energy access as a main challenge. The current "first come, first served" principle regulating the electricity distribution makes it impossible to guarantee energy access unless it is pre-ordered. To avoid energy-shortage, operators sometimes overestimate the energy needed for their vessels, which can result in an increase in the tender price. Increasing the grid capacity causes a non-linear increase in costs. For instance, one procurer notes that, while establishing solutions, $0.7 \mathrm{MW}$ charging may cost NOK 10 million, and required infrastructural adjustments causes 
an energy increase to $1 \mathrm{MW}$ to cost as much as NOK 200 million. The fluctuating grid tariff also presents uncertainty and extra costs to the operators, and one interviewee calls for a specific grid tariff for electric ferries in order to provide more stability and predictability.

Infrastructure and charging/refueling: As seen above, the infrastructure to support zero-emission transport remains costly and the operators' technology choices partly depend on whether their projects are eligible for financial support to cover infrastructure costs. The lack of standards in charging infrastructure and the multitude of solutions make fleets less flexible and less interchangeable. The installations also need to comply with existing zoning plans. The interviews show that long-lasting planning processes may delay the implementation of land-based infrastructure. Moreover, limited power effect and capacity, minimum operation time requirements, and route schedules that do not incorporate charging make operators choose hybrid solutions over fully electric vessels.

\section{Discussion and Conclusions}

The purpose of this paper has been to explore the practices of governance in transitioning maritime transport toward sustainability, with a particular focus on green public procurement of maritime passenger transport services.

The calls for tender for ferry services typically place environmental requirements on vessels through requiring specific technologies or specific emission limits. In most cases, the operators themselves are responsible for financing the modification of quays and infrastructure if this is necessary for them to comply with emission or technology requirements. Although these costs are added to the operators' tender price, other costs can be reduced if the operator implements solutions that release financial support from Enova or the $\mathrm{NO}_{\mathrm{x}}$ fund. Tenders are typically evaluated according to both economic and environmental criteria, although their definitions and weights differ from one call to another. A handful of calls further warn that successful bidders will be subject to monitoring and reporting to ensure sufficiently low emission levels.

Through interviews with procurers and operators of ferry services, this study also identifies issues that are critical for accelerating sustainability transitions in maritime passenger transport. These issues are placed in two categories: procedural issues relate to timelines, contract length, standardization, requirements, and environmental weight, whereas service delivery issues relate to technology lock-in, technology costs, energy capacity and costs, and infrastructure. The service providers raise some issues for procuring authorities to consider for future calls for tender, such as standardization of requirements, sanctions and weights in the evaluation process, and applying emission criteria instead of technological criteria for environmental aspects. Timetables not allowing sufficient time for charging, lack of standards in charging infrastructure, and associated division of responsibility for investments, costs, and maintenance as well as capacity restriction in the power grid are also pointed to as obstacles toward accelerated uptake of zero-emission propulsion solutions.

Based on the experiences of the interviewees in this study, green public procurement can be considered as a representation of the different governance mechanisms described earlier [9]. Green public procurement of ferry services on national roads holds clear regulatory traits through national requirements for zero-emissions solutions. These national requirements, along with their influence on all public procurement, can be expected to install meaning and value concerning what is a good ferry service and can strengthen the normative competitiveness of operators who deliver sufficiently sustainable solutions. To a certain degree, green public procurement of ferry services also serves to align cognitive orientations, as they appear to create a common acceptance and acknowledgement of the need for transitioning maritime passenger transport. Although green public procurement does not necessarily favor a specific technology, it seems to facilitate a fair consensus about objectives and ambitions, therein unifying perceptions and understandings of the future. Overall, however, green public procurement of ferry services is an obvious example of market mechanisms being used to progress sustainable technologies, which in addition to the procurement itself includes the incorporation of other support schemes and (dis)incentives (e.g., Enova and $\mathrm{NO}_{\mathrm{x}}$ tax/fund). As such, 
green public procurement of ferry services has in itself created a market for sustainable maritime passenger transport in Norway.

Norwegian authorities take an active role in promoting low- and zero-emission solutions in maritime transport. In the passenger segment, national and regional authorities have explicit ambitions of facilitating transitions through green public procurement of ferry services. As such, they contribute to overcome barriers toward sustainable technologies in transport described earlier in this paper [19-21]. For one, the green public procurement strategies in the ferry segment install service and technology providers with direction, albeit for a definite period, which increases willingness to invest and reduces risk perceptions. Secondly, in providing a market for emerging technologies, green public procurement also ensures predictability and encourages ambition among tenderers. It is also important to note the heavy political and corporate anchoring within which these procurement strategies are molded and the fruitful private-public cooperation that they appear to produce. Green public procurement therefore holds particular promise for progressing sustainability transitions in maritime transport because it targets a segment (i.e., domestic ferry services) falling entirely under the jurisdiction of Norwegian authorities. As such, barriers associated with lack of common policies enforced by strong institutions that hamper transitions in international maritime transport are rendered irrelevant.

Hoogma et al. [20] pointed to inadequate regulations as a barrier for sustainable technologies. One example of that highlighted by interviewees in this study are regulations in the energy market. The rapid technology development makes it difficult to predict expected energy demand in advance before final technology solution is developed and implemented, but because of the "first come, first served" principle, operators must predict and pre-order the energy in order to secure the operation of future zero-emission vessels.

An interesting issue for securing predictability and reducing risks for operators are the different practices for distributing responsibility and costs associated with establishing or modifying quays and infrastructure. Without common directions and guidelines for technological solutions, there is a risk that different operators establish a variety of solutions. This would move infrastructure even further away from standardization, reduce fleet flexibility, and increase costs as infrastructure must be rebuilt or modified when contracts expire and new operators, whose vessels are not compatible with infrastructure solutions, are to operate the connection.

The operators interviewed in this study represent a substantial share of the market they engage in, and with two other operators, do win most tenders for ferry services in Norway. As such, they can be expected to hold particular sway over governance approaches to sustainable transitions [19]. In the same way, the three interviews with procurers covering the majority of procuring practices can be expected to represent the point of view of a majority of the procurers since the NPRA have standardized contracts for all ferry connections on national roads. Those contracts are also applied on several county road connections since county administrations in many cases request the NPRA to handle the procurement process for them.

Still, there are a number of other maritime passenger transport services (school routes, city ferries, and high-speed vessels) subject to public procurement that are not included in this study. This implies that the study does not include valuable perspectives of smaller ferry operators or the perspectives of operators of maritime passenger transport services other than car-and-passenger ferries. As these can be expected to hold other resources and potentially orient toward other markets, they might have diverging perceptions of critical issues in green public procurement.

Further, the study does not explicitly focus on operators' perspectives on calls for tender where they have been unsuccessful. This, in combinations with interviewing operators who do not succeed in accessing the ferry market through public procurement, could provide valuable insight into green public procurement as a potential barrier toward competition and stronger environmental reorientation in larger parts of the ferry segment.

It should also be noted that the potential of governance in progressing sustainability transitions in maritime passenger transport goes beyond green public procurement. As mentioned in the 
introduction, Norwegian authorities have launched a range of instruments to facilitate emerging technologies, and these should also be included under the umbrella of green public procurement. For instance, the state enterprise Enova in the period 2015-2017 allocated nearly EUR 70 million between 17 projects in maritime passenger transport [66]. Future research should also investigate the potential of development contracts in more detail, as these are gaining ground and are currently being used to develop solutions for hydrogen high-speed vessels on coastal routes in Central Norway.

Author Contributions: The authors confirm contribution to the paper as follows: conceptualization, K.Y.B., S.M., and S.D.; methodology, K.Y.B., S.M., and S.D.; formal analysis, K.Y.B., S.M., and S.D.; investigation, H.K., K.Y.B., and S.D.; data curation, R.S.S., H.K., and K.Y.B.; writing-original draft preparation, K.Y.B., R.S.S., and H.K.; writing-review and editing, K.Y.B., R.S.S., H.K., S.M., and S.D.; project administration, S.M.; funding acquisition, S.M., K.Y.B., and S.D. All authors reviewed the results and approved the final version of the manuscript.

Funding: This research was funded by Norwegian Research Council through the MoZEES research centre (www.mozees.no), grant number 257653.

Acknowledgments: We wish to thank all interviewees for providing their perspectives.

Conflicts of Interest: The authors declare no conflict of interest. The funders had no role in the design of the study; in the collection, analyses, or interpretation of data; in the writing of the manuscript; or in the decision to publish the results.

\section{References}

1. Rotmans, J.; Kemp, R.; Van Asselt, M. More evolution than revolution: Transition management in public policy. Foresight 2001, 3, 15-31. [CrossRef]

2. Loorbach, D. Transition management for sustainable development: A prescriptive, complexity-based governance framework. Governance 2010, 23, 161-183. [CrossRef]

3. Kooiman, J. Governing as Governance; SAGE Publications: London, UK, 2003.

4. Mayntz, R. New challenges to governance theory. In Governance as Social and Political Communication; Bang, H.P., Ed.; Manchester University Press: Manchester, UK, 2003.

5. Stoker, G. Governance as theory: Five propositions. Int. Soc. Sci. J. 1998, 50, 17-28. [CrossRef]

6. Lemos, M.C.; Agrawal, A. Environmental Governance. Annu. Rev. Environ. Resour. 2006, 31, 297-325. [CrossRef]

7. Schneider, V. State Theory, Governance and the Logic of Regulation and Administrative Contro. In Governance in Europe: The Role of Interest Groups; Warntjen, A., Wonka, A., Eds.; Nomos Publishers: Baden-Baden, Germany, 2004.

8. Fukuyama, F. What is Governance? Governance 2013, 26, 347-368. [CrossRef]

9. Hillman, K.; Nilsson, M.; Rickne, A. Fostering sustainable technologies: A framework for analysing the governance of innovation systems. Sci. Public Policy 2011, 38, 403-415. [CrossRef]

10. Tukker, A.; Butter, M. Governance of sustainable transitions: About the 4(0) ways to change the world. J. Clean. Prod. 2007, 15, 94-103. [CrossRef]

11. Kemp, R.; Parto, S.; Gibson, R.B. Governance for sustainable development: Moving from theory to practice. Int. J. Sustain. Dev. 2005, 8, 12-30. [CrossRef]

12. Smith, A.; Stirling, A.; Berkhout, F. The governance of sustainable socio-technical transitions. Res. Policy 2005, 34, 1491-1510. [CrossRef]

13. STRN. A Research Agenda for the Sustainability Transitions Research Network. In Sustainability Transitions Research Network; University of Manchester: Manchester, UK, 2017.

14. Loorbach, D.; Rotmans, J. The practice of transition management: Examples and lessons from four distinct cases. Futures 2010, 42, 237-246. [CrossRef]

15. Markard, J.; Raven, R.; Truffer, B. Sustainability transitions: An emerging field of research and its prospects. Res. Policy 2012, 41, 955-967. [CrossRef]

16. Voß, J.-P.; Bauknecht, D.; Kemp, R. Reflexive Governance for Sustainable Development; Edward Elgar Publishing: Cheltenham, UK, 2006.

17. Van Leeuwen, J. The regionalization of maritime governance: Towards a polycentric governance system for sustainable shipping in the European Union. Ocean Coast. Manag. 2015, 117, 23-31. [CrossRef]

18. Lister, J.; Poulsen, R.T.; Ponte, S. Orchestrating transnational environmental governance in maritime shipping. Glob. Environ. Chang. 2015, 34, 185-195. [CrossRef] 
19. Roe, M. Maritime Governance and Policy-making: The Need for Process Rather than form. Asian J. Shipp. Logist. 2013, 29, 167-186. [CrossRef]

20. Hoogma, R.; Kemp, R.; Schot, J.; Truffer, B. Experimenting for Sustainable Transport. In The Approach of Strategic Niche Management; Routledge: London, UK, 2002.

21. Nilsson, M.; Nykvist, B. Governing the electric vehicle transition-Near term interventions to support a green energy economy. Appl. Energy 2016, 179, 1360-1371. [CrossRef]

22. Fenton, $P$. The role of port cities and transnational municipal networks in efforts to reduce greenhouse gas emissions on land and at sea from shipping-An assessment of the World Ports Climate Initiative. Mar. Policy 2017, 75, 271-277. [CrossRef]

23. Gibbs, D.; Rigot-Muller, P.; Mangan, C.; Lalwani, C. The role of sea-ports in end-to-end maritime transport chain emissions. Energy Policy 2014, 64, 337-348. [CrossRef]

24. Poulsen, R.T.; Ponte, S.; Sornn-Friese, H. Environmental upgrading in global value chains: The potential and limitations of ports in the greening of maritime transport. Geoforum 2018, 89, 83-95. [CrossRef]

25. ESPO. Trends in EU Ports Governance 2016; European Sea Ports Organisation: Brussels, Belgium, 2016.

26. OECD. Available online: http://www.oecd.org/gov/public-procurement/ (accessed on 23 January 2019).

27. Testa, F.; Iraldo, F.; Frey, M.; Daddi, T. What factors influence the uptake of GPP (green public procurement) practices? New evidence from an Italian survey. Ecol. Econ. 2012, 82, 88-96. [CrossRef]

28. European Commission. Buying Green! A Handbook on Green Public Procurement; European Commission: Luxembourg, 2016.

29. Brammer, S.; Walker, H. Sustainable procurement in the public sector: An international comparative study. Int. J. Op. Prod. Manag. 2011, 31, 452-476. [CrossRef]

30. Aldenius, M.; Khan, J. Strategic use of green public procurement in the bus sector: Challenges and opportunities. J. Clean. Prod. 2017, 164, 250-257. [CrossRef]

31. Aschhoff, B.; Sofka, W. Innovation on demand-Can public procurement drive market success of innovations? Res. Policy 2009, 38, 1235-1247. [CrossRef]

32. Appelt, S.; Galindo-Rueda, F. Measuring the Link between Public Procurement and Innovation; OECD: Paris, France, 2016.

33. Rainville, A. Standards in green public procurement-A framework to enhance innovation. J. Clean. Prod. 2017, 167, 1029-1037. [CrossRef]

34. Uyarra, E. The impact of public procurement of innovation. In Handbook of Innovation Policy Impact; Edler, J., Cunningham, P., Gök, A., Shapira, P., Eds.; Elgar: Cheltenham, UK; Northampton, UK, 2016.

35. Penyalver, D.; Turró, M. Measuring the value for money of transport infrastructure procurement; an intergenerational approach. Transp. Res. Part A Policy Pract. 2019, 119, 238-254. [CrossRef]

36. Cui, C.; Liu, Y.; Hope, A.; Wang, J. Review of studies on the public-private partnerships (PPP) for infrastructure projects. Int. J. Proj. Manag. 2018, 36, 773-794. [CrossRef]

37. Keränen, O. Roles for developing public-private partnerships in centralized public procurement. Ind. Mark. Manag. 2017, 62, 199-210. [CrossRef]

38. Torvinen, H.; Ulkuniemi, P. End-user engagement within innovative public procurement practices: A case study on public-private partnership procurement. Ind. Mark. Manag. 2016, 58, 58-68. [CrossRef]

39. Moe, C.E.; Newman, M.; Sein, M.K. The public procurement of information systems: Dialectics in requirements specification. Eur. J. Inf. Syst. 2017, 26, 143-163. [CrossRef]

40. Soliño, A.S.; Gago de Santos, P. Transaction Costs in Transport Public-Private Partnerships: Comparing Procurement Procedures. Transp. Rev. 2010, 30, 389-406. [CrossRef]

41. Uttam, K.; Roos, C.C.L. Competitive dialogue procedure for sustainable public procurement. J. Clean. Prod. 2015, 86, 403-416. [CrossRef]

42. Direktoratet for Forvaltning Og IKT, Konkurranse Med Forhandlinger. Available online: https://www. anskaffelser.no/avtaler-og-regelverk/anskaffelsesprosedyrer/konkurranse-med-forhandlinger (accessed on 7 December 2018).

43. Direktoratet for Forvaltning Og IKT, Konkurransepreget Dialog. Available online: https://www.anskaffelser. no/avtaler-og-regelverk/anskaffelsesprosedyrer/konkurransepreget-dialog (accessed on 7 December 2018).

44. Direktoratet for Forvaltning Og IKT, Forsknings-og utviklingskontrakter-trakter. Available online: https: //www.anskaffelser.no/avtaler-og-regelverk/anskaffelsesprosedyrer/forsknings-og-utviklingskontrakter (accessed on 7 December 2018). 
45. Cheng, W.; Appolloni, A.; D'Amato, A.; Zhu, Q. Green Public Procurement, missing concepts and future trends-A critical review. J. Clean. Prod. 2018, 176, 770-784. [CrossRef]

46. Alhola, K. Environmental criteria in public procurement. In Focus on Tender Documents; Boreal Environment Research: Helsinki, Finland, 2012.

47. Palmujoki, A.; Parikka-Alhola, K.; Ekroos, A. Green public procurement: Analysis on the use of environmental criteria in contracts. Rev. Eur. Community Int. Environ. Law 2010, 9, 250-262. [CrossRef]

48. Fet, A.M.; Michelsen, O.; Boer, L. Green public procurement in practice -the case of Norway. Soc. Econ. 2011, 33, 183-198. [CrossRef]

49. Michelsen, O.; de Boer, L. Green procurement in Norway; a survey of practices at the municipal and county level. J. Environ. Manag. 2009, 91, 160-167. [CrossRef] [PubMed]

50. Lambert, N.; Solevåg, Ø. Kartlegging av Statlige Anskaffelser. In Vurdering av Oppfølging av Regjeringens Handlingsplan for Miljø Og Samfunnsansvar i Offentlige Anskaffelser 2007-2010; Bergfald \& Co.: Oslo, Norway, 2010.

51. Inventura. Ivaretakelse av Miljøaspekter i Offentlige Anskaffelser, Status 2015; Inventura: Bergen, Norway, 2016.

52. Gelderman, C.J.; Ghijsen, P.W.T.; Brugman, M.J. Public procurement and EU tendering directives-explaining non-compliance. Int. J. Public Sect. Manag. 2006, 19, 702-714. [CrossRef]

53. Grandia, J. Finding the missing link: Examining the mediating role of sustainable public procurement behaviour. J. Clean. Prod. 2016, 124, 183-190. [CrossRef]

54. Gelderman, C.J.; Cees, J.; Semeijn, J.; Vluggen, R. Development of sustainability in public sector procurement. Public Money Manag. 2017, 37, 435-442. [CrossRef]

55. Testa, F.; Annunziata, E.; Iraldo, F.; Frey, M. Drawbacks and opportunities of green public procurement: An effective tool for sustainable production. J. Clean. Prod. 2016, 112, 1893-1900. [CrossRef]

56. Ministry of Transport and Communications. National Transport Plan 2018-2029; Ministry of Transport and Communications: Oslo, Norway, 2017.

57. Norwegian Ministry of Climate and Environment. New Emission Commitment for Norway for 2030-Towards Joint Fulfilment with the EU; Norwegian Ministry of Climate and Environment: Oslo, Norway, 2014-2015.

58. The Norwegian Tax Administration. Available online: https:/www.skatteetaten.no/satser/saravgift--mineralske-produkter/ (accessed on 7 March 2019).

59. Agency for Public Management and Egovernment. Available online: https://www.difi.no/blogg/2017/08/ gronne-offentligeanskaffelser-hva-er-det-og-hvorfor-er-det-viktig (accessed on 7 March 2019).

60. Denzin, N. Introduction: Entering the field of Qualitative Research. In Handbook of Qualitative Research; Denzin, N., Lincoln, Y.S., Eds.; Sage: Thousand Oaks, CA, USA, 1994.

61. Berg, B.L. Qualitative Research Methods for the Social Sciences; Allyn \& Bacon: Boston, MA, USA, 2001.

62. Onwuegbuzie, A.J.; Leech, N.L. Sampling Designs in Qualitative Research: Making the Sampling Process More Public. Qual. Rep. 2007, 12, 238-254.

63. Tongco, D.C. Purposive Sampling as a Tool for Informant Selection. Ethnobot. Res. Appl. 2007, 5, 147-158. [CrossRef]

64. Thagaard, T. Systematikk og innlevelse. In En Innføring i Kvalitativ Metode; Fagbokforlaget: Oslo, Norway, 2002.

65. Bergman, M.A.; Lundberg, S. Tender evaluation and supplier selection in public procurement. J. Purch. Supply Manag. 2013, 19, 73-83. [CrossRef]

66. Bjerkan, K.Y.; Sondell, R.S.; Karlsson, H.; Damman, S.; Meland, S. Public tendered maritime passenger services. In Opportunities and Barriers for Zero-Emission Operation; SINTEF: Trondheim, Norway, 2019.

(C) 2019 by the authors. Licensee MDPI, Basel, Switzerland. This article is an open access article distributed under the terms and conditions of the Creative Commons Attribution (CC BY) license (http://creativecommons.org/licenses/by/4.0/). 